\title{
Transient Stability Analysis of Shipboard Hybrid Power Generation for Trimaran Ferry as the Inter - Island Cruise in Indonesia
}

\author{
Indra Ranu Kusuma a,*, Semin ${ }^{b}$, M. Badrus Zaman' ${ }^{c}$ and Firman Aziz Nugrohod \\ Departement of Marine Engineering, Institut Teknologi Sepuluh Nopember, Kampus ITS Keputih \\ Sukolilo - Surabaya, Indonesia \\ a.Irkusuma97@gmail.com,b.semin@its.ac.id,c.druz_zaman@ne.its.ac.id, \\ d.firman.aziz@outlook.com \\ *Irkusuma97@gmail.com
}

Keywords: $\quad$ Ship Electrical System, Hybrid Power System, Voltage Stability.

Abstract: Shipboard hybrid power system (SHPS) is a concept of combining two or more different electrical energy sources to supply the requirement of electrical system loads at ship. In this research, the SHPS consists of three types power generation. There is wind turbine, photovoltaic, and diesel engine generator. Hybrid power system has contributed more fault current occurred. The aim of transient stability of hybrid power is to maintain the synchronization of generating power with share load in the SHPS. In this paper, it has been investigated that every SHPS will operate in normal condition. Then, there is major problem occurred suddenly in the grid. The grid should be able to maintain stability and should avoid the loss of synchronization. The capability to restore should comply with Class. There are six case studies has been done in this research and the simulation results of transient voltage stability are accepted with meet the recovery time (2s) and voltage transient tolerance values $( \pm 16 \%)$ according from standard BKI (Indonesian Class Society).

\section{Introduction}

Recently, the application of hybrid systems on shipboard, both for propulsion systems and power generation systems are become important environment issues [1]. The main benefit of using the hybrid system is in order to support the development of the eco-friendly ship technology in the midst of global warming issues [2].

Shipboard hybrid power system (SHPS) with one or more stochastic energy sources tend to contribute more fault current therefore making the system vulnerable to instability [3]. This research concerns about dynamic performance of the hybrid shipboard power generation of trimaran Ferry, see Figure 1. 


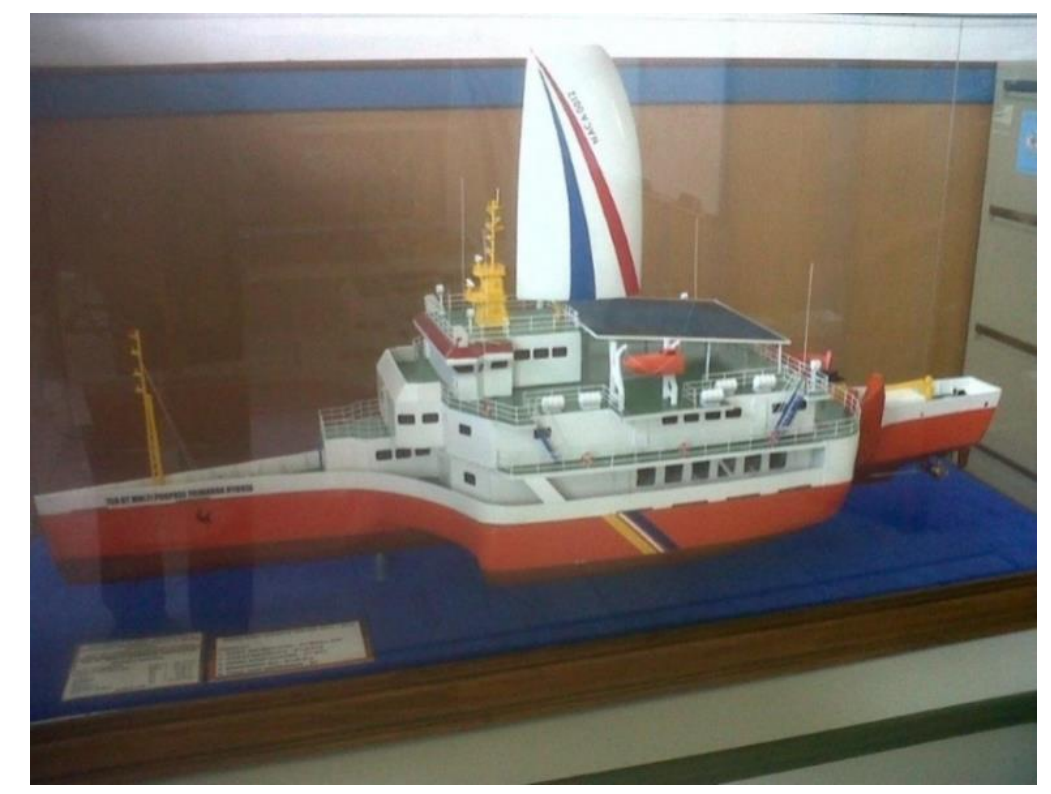

Figure 1: Trimaran Ferry with Hybrid Distributed Generation (Source: Aries Sulisetyono et al., Insentif Riset Sinas, 2012)

This paper concerns about stability performance of the hybrid shipboard power generation of trimaran Ferry. Transient stability is an ability of electrical system to maintain the synchronization and balance of hybrid generating power with loading power in the system [4]. In this case, every generator in ship electrical system and DC source will operate normally. Then, major problems that may occur suddenly, such as the outage the generator, loss of one electric resources, high power starting motor, and short circuit, are capable to slowdown or even accelerate the motor rotation that make loss of synchronization may occur in the electrical power system. Ring distribution is used as the integrated electrical power system in ships, as it has the benefit of allowing the system to supply electrical powers through two or more generators. The electrical power stability response in ship is done to determine the system response due to some sudden occurring problems so the reliable recommendations can be selected, see Figure 2.

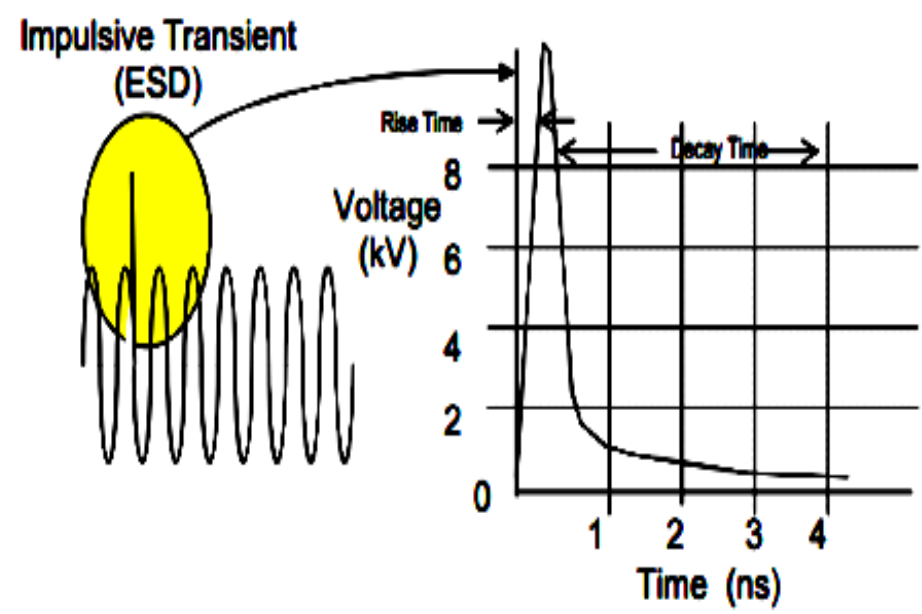

Figure 2: Positif Impulsive Transient (Source:

https://ikkholis27.wordpress.com/2013/01/28/stabilitas-transient/) 


\section{Hybrid Power Electrical Systems}

\subsection{Class Requirement for Hybrid Power System Stability}

The Indonesian Bureau of Classification (BKI) is an Indonesian State-Owned Enterprise designated as the only national classification to conduct the Indonesian and foreign shipping trade vehicles operating regularly in Indonesian territorial. The classification activity of BKI is the classification of ships based on hull construction, machinery and electric vessel with the aim of providing a technical assessment of whether or not the ship deserves to sail. In determining the voltage and frequency of the power distribution system, BKI has a standard regarding the operating voltage limits that must be met in BKI Volume IV on the regulation of electrical installation on board. There is a standard on the operating conditions of the ship for the use of the distribution of AC \& DC equipment systems. In Table 1 and Figure 3 the following is the normal operating limit of the voltage under transient to steady state conditions. While in Table 2 is the standard operating limit of voltage for DC equipment [5].

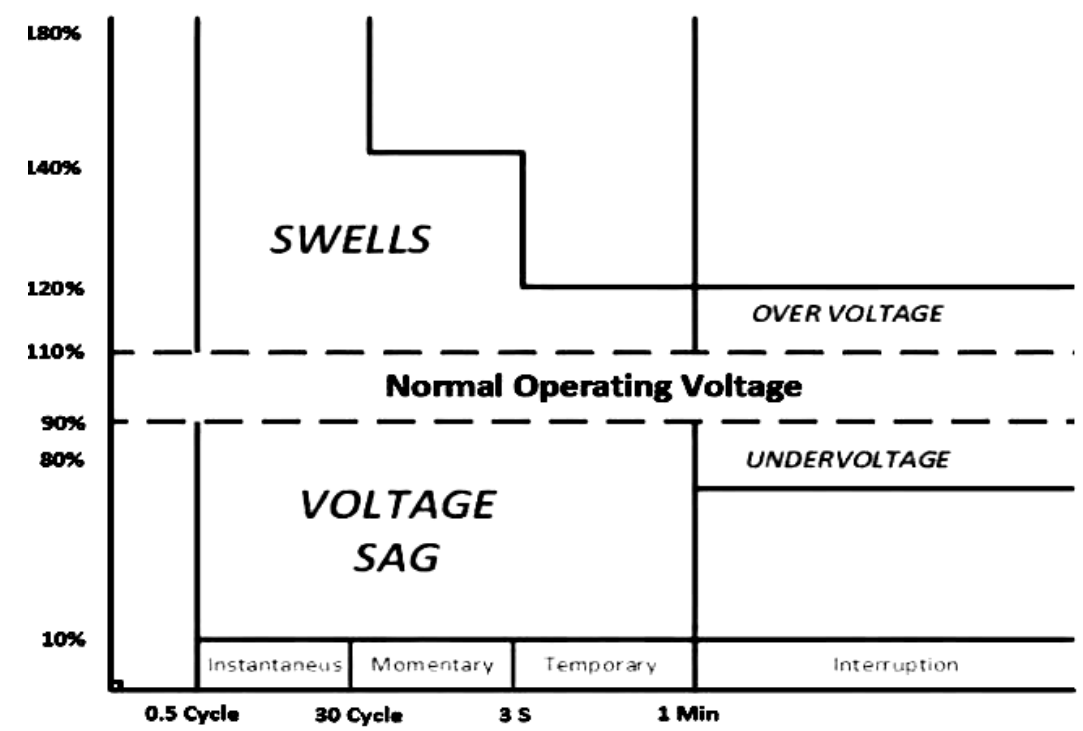

Figure 3: Standard operating voltage limits of transient stability

Table 1: Voltage and frequency variations for A.C. distribution systems

\begin{tabular}{|l|c|c|}
\hline \multirow{2}{*}{ Quantity In Operation } & \multicolumn{2}{c|}{ Variations } \\
\cline { 2 - 3 } & Permanent & Transient \\
\hline Frequency & $\pm 5 \%$ & $\pm 10 \%(5 \mathrm{Sec})$ \\
\hline Voltage & $+6 \%,-10 \%$ & $\pm 20 \%(1,5 \mathrm{Sec})$ \\
\hline
\end{tabular}

Table 2: Voltage and frequency variations for D.C. distribution systems

\begin{tabular}{|l|c|}
\hline \multicolumn{1}{|c|}{ Parameters } & Variations \\
\hline Voltage Tolerance ( Continous ) & $+10 \%$ \\
\hline Voltage Cyclic Variation Deviation & $5 \%$ \\
\hline Voltage Riple ( AC rms oversteady DC voltage) & $10 \%$ \\
\hline
\end{tabular}




\section{Methodology}

Hybrid Electrical system in Trimaran Ship uses interconnection system. This system is used to improve the reliability of the system when the system is interrupted [6]. The advantage of this interconnection system is that some generators can channel power to the load so as to enable loads to supply more than 1 generator. In this paper, the Trimaran Ship hybrid electrical system is developed by using unmeshed distribution system using 2 generators, photovoltaic (dc source) and wind turbine. So when the system experienced a sudden large disruption, it resulted small current at the end point. Trimaran Ship hybrid electrical system have main bus and branch buses to be integrated into interconnection. The following is the specification data used in this ship.

\subsection{Data Design Requirement}

The formulation of this requirement is obtained from the results of field survey. Capacity of passengers and ship payload is predicted by forecasting with moving average technique and HoltWinter method. The speed of the vessel is determined by optimization method to maximal profit value and margin cost.

Table 3: Data trimaran ferry (Source: PT. Simokarleng dan BAPPEDA)

\begin{tabular}{|c|c|c|c|c|}
\hline No & \multicolumn{4}{|c|}{ Data Design Requirement } \\
\hline 1 & \multicolumn{2}{|l|}{ Type of ship } & \multicolumn{2}{|c|}{ Ferry } \\
\hline 2 & \multicolumn{2}{|l|}{ Type of Load } & \multicolumn{2}{|c|}{ Passanger and Cargo } \\
\hline 3 & \multicolumn{2}{|l|}{ Load Capacity } & \multicolumn{2}{|c|}{$300-\mathrm{Pax}$} \\
\hline 4 & \multicolumn{2}{|l|}{ Payload } & \multicolumn{2}{|c|}{$\begin{array}{l}70- \\
\text { Ton }\end{array}$} \\
\hline 5 & \multicolumn{2}{|l|}{ Velocity } & \multicolumn{2}{|l|}{$16 \mathrm{Knot}$} \\
\hline 6 & \multicolumn{2}{|l|}{ Bunkering Port } & \multicolumn{2}{|l|}{ Kalianget } \\
\hline \multirow[t]{3}{*}{7} & \multicolumn{2}{|l|}{ Class } & \multicolumn{2}{|l|}{ BKI } \\
\hline & Rute & & Radius & Time \\
\hline & Kalianget - Kangean & \multicolumn{2}{|c|}{96 mil } & 6 hours \\
\hline \multirow[t]{3}{*}{8} & Kangean - Sapeken & \multicolumn{2}{|c|}{$40 \mathrm{mil}$} & 2.5 hours \\
\hline & Sapeken - Masalembu & \multicolumn{2}{|c|}{$125 \mathrm{mil}$} & 7.8 hours \\
\hline & Total & \multicolumn{2}{|c|}{$261 \mathrm{mil}$} & 16 hours \\
\hline
\end{tabular}

\subsection{Principal Dimension}

The initial primary size determination is taken from the main size of the comparative vessel, and "M.V. Sea Flower", taken as a parent ship. The optimization process is carried out on technical and economic analysis, until the optimum size of the trimaran vessel is obtained. 
Table 4: Principal Dimension

\begin{tabular}{|c|c|c|c|c|}
\hline No & Dimensions & Main hull & Side hull & Unit \\
\hline 1 & $\mathrm{~L}$ & 54.53 .00 & 16.632 & {$[\mathrm{~m}]$} \\
\hline 2 & B & 3.642 & 0,67013889 & {$[\mathrm{~m}]$} \\
\hline 3 & $\mathrm{~T}$ & 1.820 & 0,67013889 & {$[\mathrm{~m}]$} \\
\hline 4 & $\mathrm{H}$ & 4.551 & 3.696 & {$[\mathrm{~m}]$} \\
\hline 5 & $\mathrm{Cb}$ & 0,35138889 & 0,35208333 & \\
\hline 6 & $\mathrm{Cm}$ & 0,64027778 & 0,64097222 & \\
\hline 7 & $\mathrm{Cp}$ & 0,38125 & 0,38194444 & \\
\hline 8 & Cwp & 0,46527778 & 0,46666667 & \\
\hline 9 & $\begin{array}{c}\text { LCB } \\
\text { midship }\end{array}$ & -2.750 & -2.705 & {$[\mathrm{~m}]$} \\
\hline 10 & $\nabla$ & 182.800 & 7.859 & [m3] \\
\hline 11 & $\Delta$ & 187.370 & 8.056 & [Ton] \\
\hline 12 & Vs & \multicolumn{2}{|c|}{16} & [knot] \\
\hline
\end{tabular}

The calculation of trimaran ship resistance refers to the book Multi-Hull Ship written by V. Dubrovsky and A. Lyakhoviysky [7]. In the book described that the total resistance trimaran is the accumulation of the respective resistance of main hull and interference barrier between hulls. The resistance of each hull is calculated individually on each of the hulls performed by the same method with the calculations on the mono hull ship. The method used to calculate these individual resistance is the Holtrop method on Principles of Naval Architecture, Volume II Resistance, Propulsion and Vibration by Lewis, Edward V.

Table 5: power calculation of trimaran ferry

\begin{tabular}{|c|c|}
\hline Parameters Design & Value \\
\hline Total Resistance & $12.31596 \mathrm{kN}$ \\
\hline EHP & $101.365 \mathrm{~kW}$ \\
\hline THP & $119.326 \mathrm{~kW}$ \\
\hline DHP & $221.38 \mathrm{~kW}$ \\
\hline SHP & $225.90 \mathrm{~kW}$ \\
\hline \multirow{2}{*}{ BHP } & $268,452 \mathrm{~kW}$ \\
& $360 \mathrm{HP}$ \\
\hline
\end{tabular}

\subsection{Hybrid Trimaran Ferry Prime mover}

The selected diesel engine type is Caterpillar $3406 \mathrm{C}$ and electrical engine is 3-Phase Squirrel Cage Induction Motors with the following specifications: 
Table 6: Diesel Engine and electric engine Spesification

\begin{tabular}{|c|c|}
\hline Engine Parameters & Value \\
\hline Bore & $137.2 \mathrm{~mm}(5.4 \mathrm{in})$ \\
\hline Stroke & $165.1 \mathrm{~mm}(6.5 \mathrm{in})$ \\
\hline Displacement & $14.64 \mathrm{~L}(893.39 \mathrm{in} 3)$ \\
\hline Engine Speed $(\mathrm{rpm})$ & 1800 \\
\hline Engine Power $(\mathrm{bhp})$ & 360 \\
\hline Engine Power $(\mathrm{kW})$ & 269 \\
\hline Engine Torque $(\mathrm{lb} \cdot \mathrm{ft})$ & 1050 \\
\hline BSFC $(\mathrm{lb} / \mathrm{bhp}-\mathrm{hr})$ & 0.340 \\
\hline Fuel Rate $(\mathrm{gal} / \mathrm{hr})$ & 17.5 \\
\hline Aspiration & Turbocharged/ After cooled \\
\hline
\end{tabular}

\subsection{Electric Load Calculation}

Electricity load from the components on the Trimaran General Cargo Passenger Ship are divided into 4 main buses. There are machinery system part, deck machinery part, refrigeration \& ventilation part, and electrical part.

Table 7: Electrical Load

\begin{tabular}{|c|c|}
\hline Electrical Load & KW \\
\hline Machinery System Part & 140,25 \\
\hline Deck Machinery Part & 120 \\
\hline Electrical Part & 19,6 \\
\hline Refrigeration \& Ventilation Part & 18,4 \\
\hline
\end{tabular}

This research is focused when ship in sailing condition. We can look in table VIII for sailing condition electrical load. There are divided to 4 condition like sailing, manoeuvring, at port, and loading unloading. It's important to make electrical load condition calculation. This calculation is refers to the book "Diktat Perencanaan Listrik Kapal" written by Sardono Sarwito.

Table 8: Electrical Load for Sailing Condition

\begin{tabular}{|c|c|c|c|}
\hline No. & \multicolumn{2}{|r|}{ Equipment } & Sailing \\
\hline 1 & $\begin{array}{l}\text { MACHINERY } \\
\text { PART }\end{array}$ & $\begin{array}{l}\text { : Continue load } \\
\text { : Intermitten load }\end{array}$ & $\begin{array}{l}84,42 \\
27,51\end{array}$ \\
\hline 2 & HULL PART & $\begin{array}{l}\text { : Continue load } \\
\text { : Intermitten load }\end{array}$ & $\begin{array}{c}26,57 \\
0,00\end{array}$ \\
\hline 3 & $\begin{array}{c}\text { ELECTRICAL } \\
\text { PART } \\
\end{array}$ & $\begin{array}{l}\text { : Continue load } \\
\text { : Intermitten load }\end{array}$ & $\begin{array}{c}16,04 \\
0,67 \\
\end{array}$ \\
\hline 4 & $\begin{array}{l}\text { Total Used } \\
\text { Power(d) }\end{array}$ & $\begin{array}{l}\text { : Continue load } \\
\text { : Intermitten load }\end{array}$ & $\begin{array}{c}127,03 \\
28,18 \\
\end{array}$ \\
\hline 5 & Broken Factor (e) & $0,6 \quad \mathrm{x}(\mathrm{d})$ intermitten & 16,91 \\
\hline 6 & Total Load & : (d) continue $+(\mathrm{e})$ & 143,93 \\
\hline 7 & Work Generator & kW x S.set & $88 \times 2$ \\
\hline 8 & Work Capacity & & 176 \\
\hline 9 & Available Generator & $\mathrm{kW} \times$ S.set & $88 \times 2$ \\
\hline 10 & Load Factor & $(\mathrm{f}) /(\mathrm{h}) \times 100 \%$ & 81,78 \\
\hline
\end{tabular}




\subsection{Generator Capacity}

After the total electrical load is calculated, and then made a comparison and selected generator based from calculation Table 9, in the table below which has a load factor value between 80-85\% for efficient operation is:

Table 9: Specification of Selected Generator

\begin{tabular}{|c|c|}
\hline Spec & Generator \\
\hline Quantity & 3 \\
\hline Power (KW) & 88 \\
\hline Voltage (Volt) & 380 \\
\hline Rotation (RPM) & 1500 \\
\hline Frequency (Hz) & 50 \\
\hline
\end{tabular}

\subsection{Photovoltaic Capacity}

Photovoltaic used for this research after calculated and compared from 5 photovoltaic models is:

Table 10: Specification of Photovoltaic

\begin{tabular}{|r|c|c|}
\hline \multicolumn{3}{|c|}{ Sunivan ART 205-60-3 } \\
\hline Maximum power $=$ & 240 & Watt \\
\hline Type & \multicolumn{2}{|c|}{ Mono-crystalline } \\
\hline Maximum voltage $=$ & 29,48 & $\mathrm{~V}$ \\
\hline Maximum current $=$ & 8 & $\mathrm{~A}$ \\
\hline Sort circuit current $=$ & 8,52 & $\mathrm{~A}$ \\
\hline Open circuit voltage $=$ & 37,5 & $\mathrm{~V}$ \\
\hline Maximum system voltage $=$ & 1000 & $\mathrm{~V}$ \\
\hline Photovoltaic dimension, $\mathrm{l}=$ & 1657 & $\mathrm{~mm}$ \\
\hline $\mathrm{w}=$ & 987 & $\mathrm{~mm}$ \\
\hline $\mathrm{h}=$ & 42 & $\mathrm{~mm}$ \\
\hline Weight $=$ & 19 & $\mathrm{~kg}$ \\
\hline
\end{tabular}

\subsection{Wind Turbine Capacity}

The wind turbine used for this research is chosen base on the assumption that its size can be placed on the ship and it's selected: 
Table 11: Selected Wind Turbine

\begin{tabular}{|c|c|c|}
\hline \multicolumn{2}{|c|}{ Wind Turbine Selection } \\
\hline Brand & \multicolumn{2}{|c|}{ Aeolos } \\
\hline Type & \multicolumn{2}{|c|}{ Vertical WT } \\
\hline Model & \multicolumn{2}{|c|}{ Aeolos V 3KW } \\
\hline Rated Power & 3000 & $\mathrm{~W}$ \\
\hline Cut In Wind Speed & 2,5 & $\mathrm{~m} / \mathrm{s}$ \\
\hline Rated Wind Speed & 10 & $\mathrm{~m} / \mathrm{s}$ \\
\hline Survival Wind Speed & 55 & $\mathrm{~m} / \mathrm{s}$ \\
\hline Blade Quantity & 3 & \\
\hline Rotor Height & 3 & $\mathrm{~m}$ \\
\hline Rotor Width & 2,4 & $\mathrm{~m}$ \\
\hline Weight & 106 & $\mathrm{~kg}$ \\
\hline Rotation & 320 & $\mathrm{RPM}$ \\
\hline Swept Area & 7,2 & $\mathrm{~m} 2$ \\
\hline
\end{tabular}

\subsection{One Line Diagram.}

The Figure 4 shows one line diagram of SHPS in Trimaran Ferry.

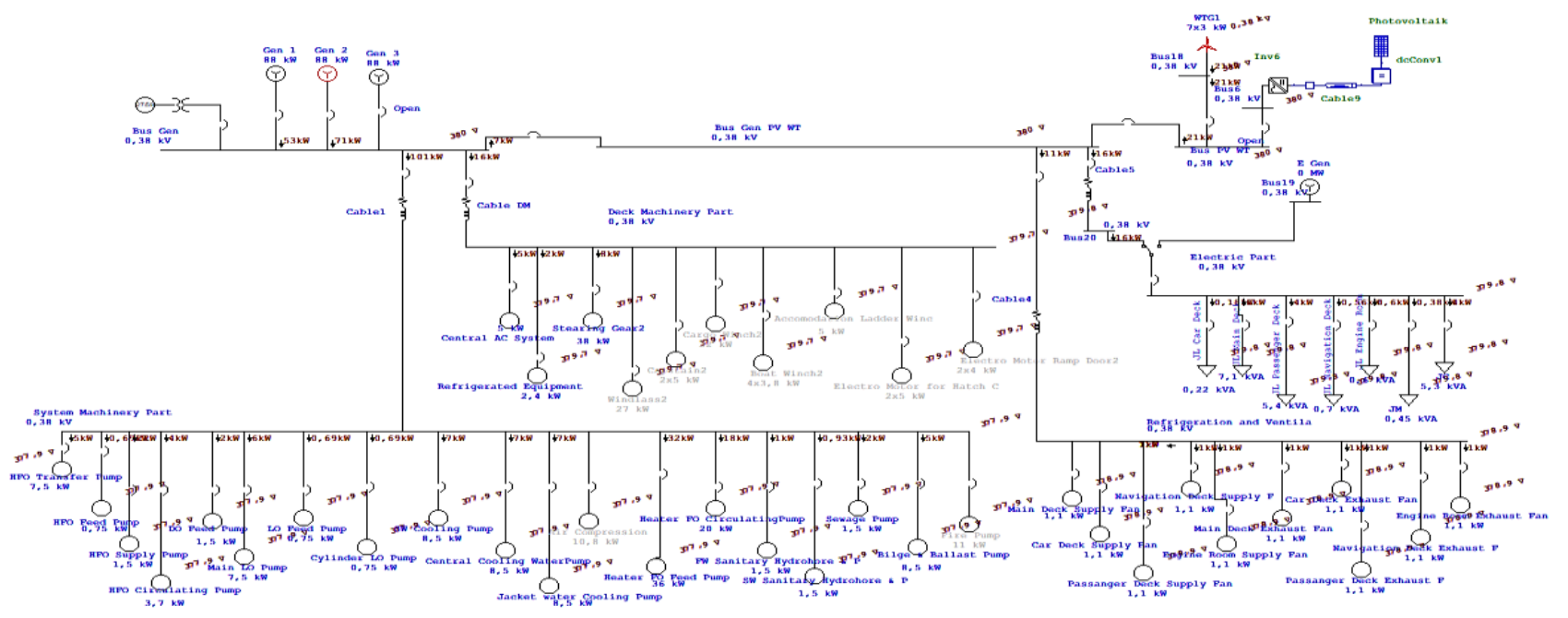

Figure 4: Single line diagram made in transient software

\section{Results and analysis}

\subsection{Scenario of Case Study}

At the time of ship sailing conditions, simulation will begin by replacing the hybrid supplied from one to other power generation between wind turbines, photovoltaics and diesel generators. Operations are varied while the system is operating. Close or open the power generation will happen with case studies variation. After that the transient response will be seen and can be analysed the system is running in acceptable standards or not. The response of the system to be monitored, among others, is the instantaneous voltage response after the system is interrupted. 
Table 12: Type Scenario of SHPS

\begin{tabular}{|c|l|l|}
\hline Number. & \multicolumn{1}{|c|}{ Case Study } & \multicolumn{1}{c|}{ Explanation } \\
\hline 1 & $\begin{array}{l}\text { Photovoltaic Operate. Photovoltaic open } \\
\text { and Generator close in "Bus Gen PV } \\
\text { WT" }\end{array}$ & $\begin{array}{l}\text { At 10 Second sudden change } \\
\text { happened in "Bus Gen PV WT". 60 } \\
\text { second simulation time. }\end{array}$ \\
\hline 2 & $\begin{array}{l}\text { Generator operate. Generator open and } \\
\text { Photovoltaic close in "Bus Gen PV WT" }\end{array}$ & $\begin{array}{l}\text { At 10 Second sudden change } \\
\text { happened in "Bus Gen PV WT". 30 } \\
\text { second simulation time. }\end{array}$ \\
\hline 3 & $\begin{array}{l}\text { Photovoltaic and wind turbine operated } \\
\text { and then open. In the same time } \\
\text { Generator close in "Bus Gen PV WT" }\end{array}$ & $\begin{array}{l}\text { At 60 Second sudden change } \\
\text { happened in "Bus Gen PV WT". 100 } \\
\text { second simulation time. }\end{array}$ \\
\hline 4 & $\begin{array}{l}\text { Generator and wind turbine operate. } \\
\text { Generator open, Photovoltaic close in } \\
\text { "Bus Gen PV WT" }\end{array}$ & $\begin{array}{l}\text { At 10 Second sudden change } \\
\text { happened in "Bus Gen PV WT". } 60 \\
\text { second simulation time. }\end{array}$ \\
\hline 5 & $\begin{array}{l}\text { Generator and Photovoltaic Operate. } \\
\text { Generator open, wind turbine close in } \\
\text { "Bus Gen PV WT" }\end{array}$ & $\begin{array}{l}\text { At 10 Second sudden change } \\
\text { happened in "Bus Gen PV WT". 60 } \\
\text { second simulation time. }\end{array}$ \\
\hline 6 & $\begin{array}{l}\text { Generator operate. Generator open, wind } \\
\text { turbine and Photovoltaic close in "Bus } \\
\text { Gen PV WT" }\end{array}$ & $\begin{array}{l}\text { At 10 Second sudden change } \\
\text { happened in "Bus Gen PV WT". 100 } \\
\text { second simulation time. }\end{array}$ \\
\hline
\end{tabular}

\subsection{Simulation Result Analysis}

\subsubsection{Photovoltaic Operate. Photovoltaic open and Generator close in "Bus Gen PV WT"}

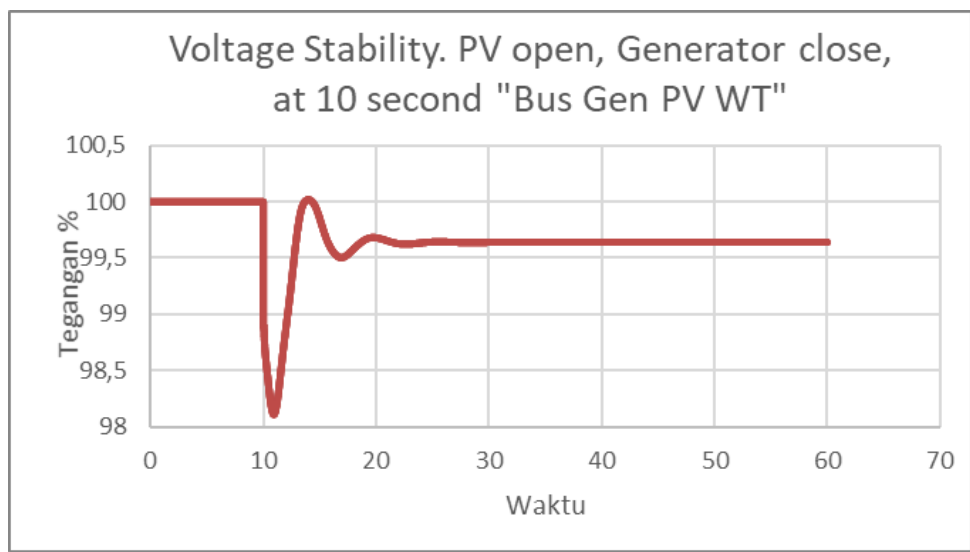

Figure 5: Photovoltaic Operate. Photovoltaic open and Generator close in "Bus Gen PV WT"

In this case study on "Bus Gen PV WT" is doing a trial if the conditions of sailing initially use photovoltaics to distribute power on "Bus Gen PV WT". Then it is assumed that environmental conditions make the performance of photovoltaics down and replaced by the operation of the diesel engine generator. In this simulation is start at 10 seconds where the photovoltaics are removed from the system and the generator goes into the "Bus Gen PV WT" to replace the previously-supplied power source photovoltaics. In the figure 5 above shows the effect of voltage stability and this can be said transient conditions. In seconds 10.941 seconds a voltage drop happens in the transient 
condition that causes the percentage value of the voltage is at $98.1 \%$ with a value of 376 Volts. The voltage returns to stable condition on percentage $99.6 \%$ with a value of 378.48 Volt. This certainly meets the standard transient voltage tolerance values but does not meet the standard recovery time of transient over 1.5 seconds according to BKI Vol IV rules

\subsubsection{Photovoltaic and wind turbine operated and then open. In the same time Generator close in "Bus Gen PV WT"}

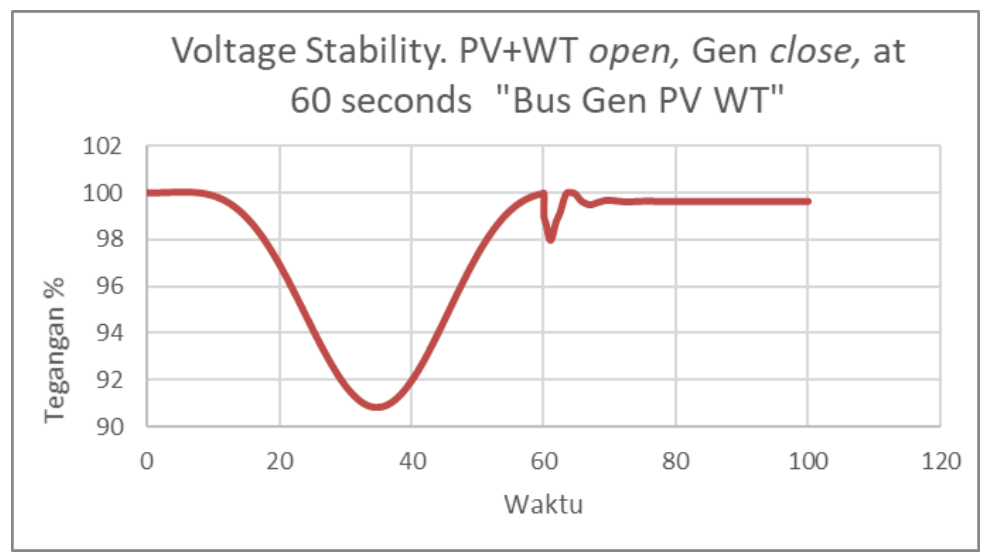

Figure 6: Photovoltaic and wind turbine operated and then open. In the same time Generator close in "Bus Gen PV WT"

In this case study on "Bus Gen PV WT" it is assumed during sailing conditions using photovoltaics and wind turbine to "Bus Gen PV WT" for 100 seconds simulation time. However, it is assumed that weather conditions do not support the performance of the two sources of wind turbine or photovoltaic, and need to be changed to diesel engine generator. The voltage stability photovoltaics and wind turbines usage is not in stable condition so that voltage controls can be provided on the bus or other technology to stabilize the voltage.

The analysis of this case study, see Figure 6, the release of photovoltaic and wind turbines is executed at 60 seconds. And at the same time the generator is operated to "Bus Gen PV WT". At 61.21 seconds a voltage drop happens causes the value of voltage percentage become $98 \%$ with 372.71 Volt. And when 70.81 second there is a voltage drop again at $99.5 \%$ with a value of 378.6 Volt. After that the voltage back to stable condition in 378.6 Volt. This certainly meets the transient standard in terms of transient voltage tolerance values but does not meet recovery time exceeding 1.5 seconds in BKI Vol IV rules.

\subsubsection{Generator and wind turbine operate. Generator open, Photovoltaic close in "Bus Gen PV WT"}

In this case study on "Bus Gen PV WT" is assumed to use generator and wind turbine during operation time for 60 seconds. It is assumed that environmental conditions are being supported to operate photovoltaic and wind turbine for power supply to the "Bus Gen PV WT" by releasing the generator at 10 seconds and at the same time entering the photovoltaic source. On the Figure 7 , there appears an understandable transient condition. The lowest point at $94.2 \%$ percentage with 357.4 Volt at 10.01 seconds. The transient condition happened and meets the standard of BKI Vol IV rules for recovery time $(1.5 \mathrm{~s})$ and transient voltage tolerance values $( \pm 20 \%)$. 


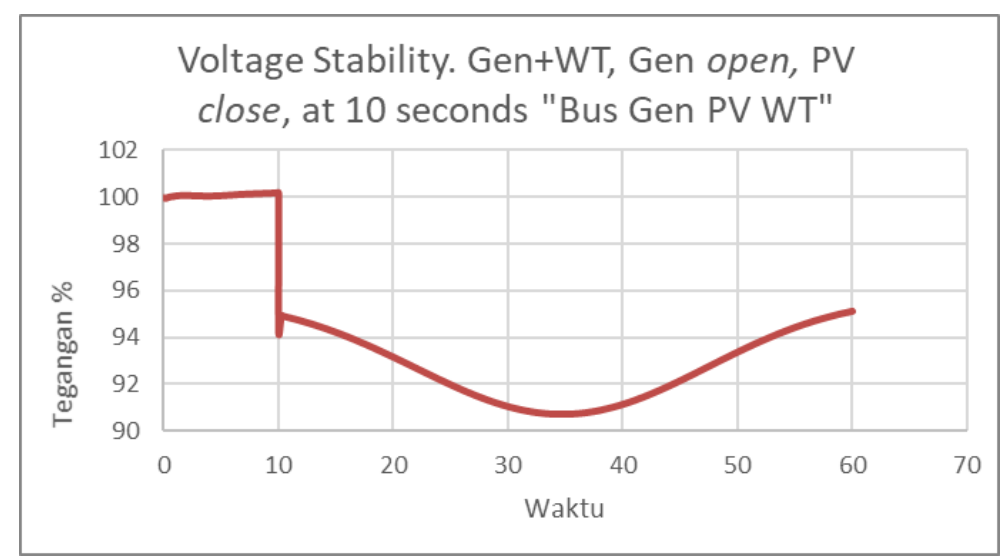

Figure 7: Generator and wind turbine operate. Generator open, photovoltaic close in "Bus Gen PV WT"

\subsubsection{Generator and Photovoltaic Operate. Generator open, wind turbine close in "Bus Gen PV WT"}

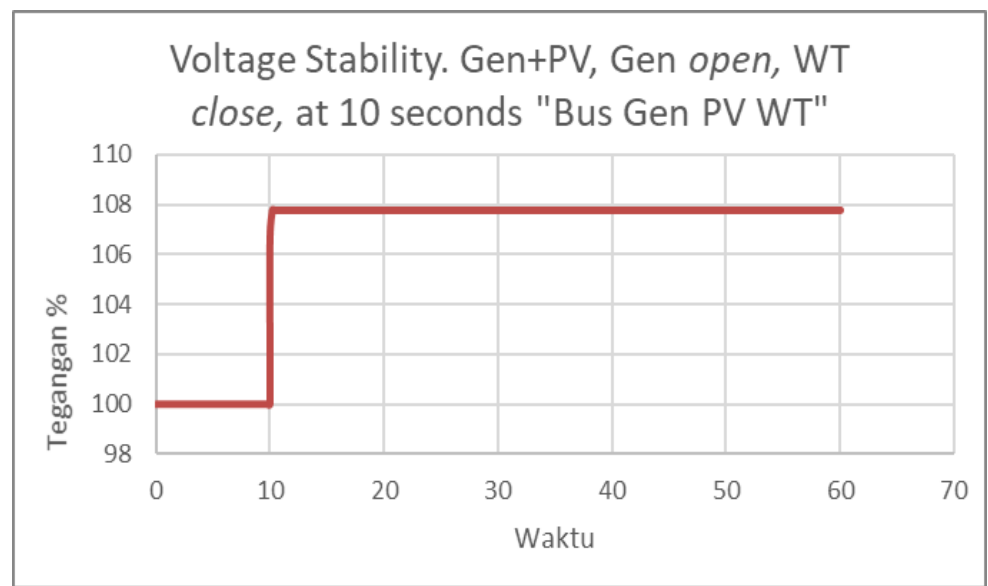

Figure 8: Generator and Photovoltaic Operate. Generator open, wind turbine close in "Bus Gen PV WT"

In this case study on "Bus Gen PV WT" using generator and photovoltaic when sailing conditions for 60 seconds. It is assumed that environmental and weather conditions are being supported to operate photovoltaics and wind turbines simultaneously to supply electricity to the "Bus Gen PV WT" by releasing the generator at 10 seconds and at the same time entering the wind turbine. In figure 8 show that the volatage increase in the value of $107.8 \%$ voltage with a value of 409.55 Volt in seconds to 10.21. Then the voltage in "Bus Gen PV WT" is stable with a percentage of $107.8 \%$ at a value of 409.55 Volts. For transient conditions is meet the requirement. But in this case study simulation at the software, wind turbine doesn't supply power to the bus. There is no reason for that. But it was related to the settings in the software used. The conclusion of this case study meet the standards for recovery time and transient voltage tolerance value of transient voltage condition in BKI Vol IV rules. 


\subsubsection{Generator operate. Generator open, wind turbine and Photovoltaic close in "Bus Gen PV WT"}

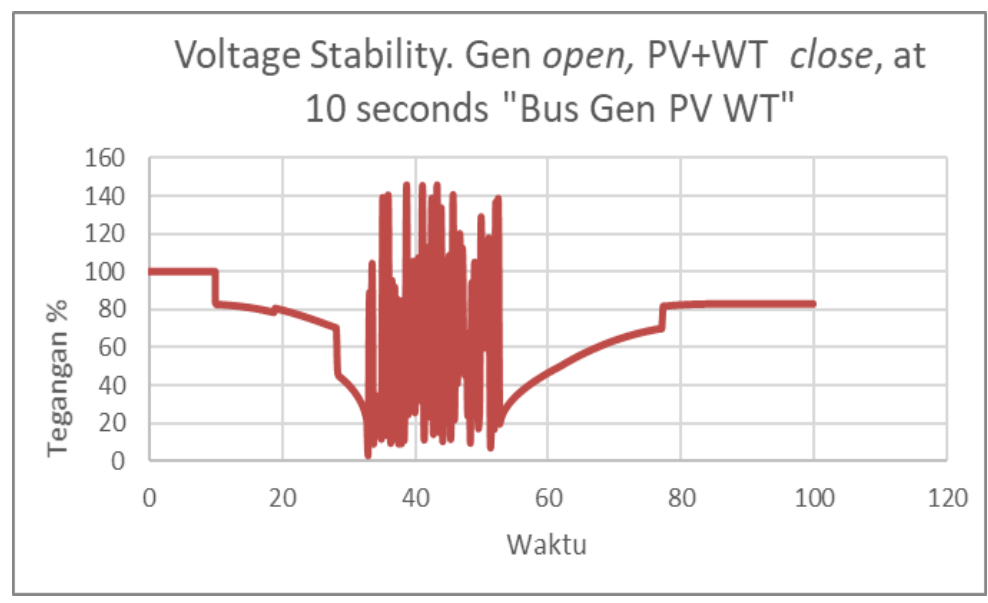

Figure 9: Generator operate. Generator open, wind turbine and Photovoltaic close in "Bus Gen PV WT"

In this case study on "Bus Gen PV WT" using a generator on sailing conditions for 100 seconds. It is assumed that weather conditions and environments support to operate wind turbines and photovoltaics on "Bus Gen PV WT". A simulation is performed at 10 second of the generator off then the wind turbine and photovoltaic is operated at the same time. There is a transient condition at the figure 9 and is still meets the requirement. But the operation of wind turbine and photovoltaic after 20 second voltage instability is happened. An under voltage occurs at 33.81 seconds with a percentage of $9.9 \%$ with a value of only 37.69 Volts for the lowest point on the graph that forms like a sinusoidal wave. And the percentage at the highest point (overvoltage) is $143.85 \%$ with a value of 546.65 volts at seconds to 43.41. Then transient condition happens at 77.41 second. After that the voltage is stable at the $82.9 \%$ percentage value with a value of 315.2 Volts. In conclusion, this case study meets the standard for recovery time but does not meet the transient voltage tolerance values when a 10 second interrupted at BKI Vol IV rules.

\section{Conclusion}

Based on the result of simulation analysis with one of transient analysis software which focused on voltage stability in hybrid power generation system, the conclusion is the simulation results when the transient voltage condition is accepted with the recovery time (1.5 seconds) and the transient voltage tolerance value $( \pm 20 \%)$ according to the BKI Vol IV rules are case studies number $4 \mathrm{~b}$, and 5 b. $4 \mathrm{~b}$ is case study about "Generator and wind turbine operate. Generator open, Photovoltaic close". And 5b is case study about "Generator and Photovoltaic Operate. Generator open, wind turbine close".

\section{Acknowledgments}

This research was supported by Institut Teknologi Sepuluh Nopember, Faculty of Marine Technology, Department of Marine Engineering. I would like to acknowledge my supervisor Prof. Semin for his supporting in this paper. Last but not least, I have to express my appreciation to head of Marine Engineering Department for sharing his pearls of wisdom with me during this research. 


\section{References}

[1] R. D. Geertsma, R. R. Negenborn, K. Visser, and J. J. Hopman, "Design and control of hybrid power and propulsion systems for smart ships: A review of developments, ” Appl. Energy, vol. 194, pp. 30-54, May 2017.

[2] Z. Jin, G. Sulligoi, R. Cuzner, L. Meng, J. C. Vasquez, and J. M. Guerrero, "Next-Generation Shipboard DC Power System: Introduction Smart Grid and dc Microgrid Technologies into Maritime Electrical Netowrks," IEEE Electrification Mag., vol. 4, no. 2, pp. 45-57, Jun. 2016.

[3] Viknash Shagar, Shantha Jayasinghe, and Hossein Enshaei, "Effect of Load Changes on Hybrid Shipboard Power Systems and Energy Storage as a Potential Solution: A Review, "Inventions, vol. 2, no. 4, p. 21, Aug. 2017.

[4] B. Zahedi and L. E. Norum, "Efficiency analysis of shipboard dc power systems, " in Industrial Electronics Society, IECON 2013-39th Annual Conference of the IEEE, 2013, pp. 689-694.

[5] BKI, "Rules for Electrical Installations Vol IV),2016.” Biro Klasifikasi Indonesia.

[6] B. Zahedi, L. E. Norum, and K. B. Ludvigsen, "Optimized efficiency of all-electric ships by dc hybrid power systems, ” J. Power Sources, vol. 255, pp. 341-354, Jun. 2014.

[7] V. Dubrovsky and Lyakhovitsky, Multi-hull ships. Backbone Pub. Co, 2001. 